\title{
EFFECTS OF HEAT-TREATMENT ON PERMEABILITY OF UNTREATED AND NANOSILVER-IMPREGNATED NATIVE HARDWOODS
}

\author{
Hamid Reza Taghiyari ${ }^{1}$
}

\begin{abstract}
The effects of heat-treatment on permeability are the main topic of the present study. Longitudinal dowel shape pairs of specimens were prepared from three native species and their specific gas permeability values were measured. From each pair, one specimen was kept for heat-treatment and the other was impregnated with $200 \mathrm{ppm}$ nano-silver suspension; the size range of nanoparticles was 20-80 nm. In six consecutive steps, each pair was heated at $50,75,100,125,150$, and $185^{\circ} \mathrm{C}$. Results showed that gas permeability increased when specimens were heated at $50^{\circ} \mathrm{C}$ as a result of the loss of bond-water and consequent shrinkage. Permeability sharply decreased when the specimens were heated at $75^{\circ} \mathrm{C}$ and gradually increased at each step up-to $150^{\circ} \mathrm{C}$. At $185^{\circ} \mathrm{C}$, permeability again decreased in. The sharp decrease in permeability at $75^{\circ} \mathrm{C}$ was possibly due to irreversible hydrogen bonding in the course of water movements within the vessel perforations and pore system of cell walls. The gradual increase in permeability at higher temperatures, though, might be due to higher internal stresses that are released as micro-cracks develop, thus leading to a greater capability of fluidtransfer. Nano-silver impregnation intensified this process.
\end{abstract}

Keywords: Nanoparticles, gas permeability, liquid permeability, perforation plate; wood modification.

\section{INTRODUCTION}

Understanding wood permeability is of vital importance as it has great impact on its utilization in different industries (such as: wood preservation, wood drying, pulp and paper) (Chen et al. 1998, Dermoe et al. 2012). Gas permeability values in solid woods can be measured with 0.001 second precision Taghiyari et al. 2010, Taghiyari and Sarvari 2010, Taghiyari 2011a) and therefore can be helpful in scientific and industrial purposes. The point is that gases usually do not have interaction with cell wall materials while liquids may come to chemical and physical interaction with it, mostly its hydroxyl groups. Besides, most industries in which permeability is important, deals with impregnation of solid woods with liquid or extraction liquids from them. Therefore, finding a correlation between gas and liquid permeabilities can be helpful for industrial decision-making processes.

The effectiveness of nano-silver impregnation has been studied on wood heat-treatment (Taghiyari 2011b), hot-press time in composite boards (Taghiyari et al. 2011), fire-retardant properties (Taghiyari 2012a), gas and liquid permeability (Taghiyari 2012b), ice-blasting (Taghiyari et al. 2012a) but little or nothing have been done on the subsequent effects of nano-silver impregnation on gas or liquid permeabilities in heat-treated solid woods. The present study is therefore aimed at analyzing the effects of heat treatment on gas and liquid permeabilities of some untreated as well as nanosilver-impregnated native hardwoods, as well as possible relationship between gas and liquid permeabilities.

\footnotetext{
${ }^{1}$ Wood Science and Technology Department, The Faculty of Civil Engineering, Shahid Rajaee Teacher Training University. Tehran, Iran. htaghiyari@yahoo.com 
The thermal modification of wood has long been recognized as a potentially useful method to improve the dimensional stabilization of wood and increase its decay resistance (Hill 2006). Although it has negative effects on the strength properties of wood, there are some techniques for mitigating these effects (Awoyemi and Westermark 2005, Awoyemi 2007).

Tiemann (1915) was one of the first workers to report on the effect of high-temperature treatment upon the physical properties of wood. He heated air-dry wood in superheated steam at $150^{\circ} \mathrm{C}$ for 4 hours, which reduced the subsequent moisture sorption by $10-25 \%$, with relatively low reductions in strength found in most cases.

At around $270^{\circ} \mathrm{C}$, there is a significant change in the reaction kinetics due to the onset of an exothermic reaction. What is less certain are the temperatures at which the different reactions become dominant (Stamm et al. 1946).

Thermal modification is usually carried out at temperatures between $180^{\circ} \mathrm{C}$ and $260^{\circ} \mathrm{C}$. Temperatures lower than $140^{\circ} \mathrm{C}$ result in only slight changes in material properties and higher temperatures result in unacceptable degradation to the substrate. Studies of the thermal treatment of wood above $300^{\circ} \mathrm{C}$ are of limited value, due to severe degradation of the material. There is also evidence to show that there is an abrupt change in the degradation kinetics close to this temperature (Elder 1991). Modern thermal modification processes are limited to temperatures no higher than $260^{\circ} \mathrm{C}$.

Temperature ranges from $150^{\circ} \mathrm{C}$ to $230^{\circ} \mathrm{C}$ are generally used for thermal modifications, because hydrolysis is very slow at lower temperatures. Cellulose degradation begins to occur in the region $210-220^{\circ} \mathrm{C}$ and becomes predominant at $270^{\circ} \mathrm{C}$. A sharp increase in the free-radical content of the wood was also found when the wood was heated at temperatures above $200^{\circ} \mathrm{C}$ (Garrote et al. 1999). The heat-transfer property of nano-silver particles on mechanical properties of heat-treated poplar was also studied (Rassam et al. 2012, Taghiyari 2011a, Taghiyari et al. 2012abc, Taghiyari 2012ab, Taghiyari and Farajpour 2013).

Heat-treatment has an effect on fluid transfer properties of wood. Reduction of wood swelling with increasing temperature and duration of thermal treatment has often been attributed to hemicelluloses destruction. However, structural modifications and chemical changes of lignin are suggested to be also involved in the process (Repellin and Guyonnet 2005). Furthermore, Borrega and Karenlampi (2010) indicated that reduction in hygroscopicity is not only due to mass loss but another mechanism may also exist. They suggest that this mechanism might be related to irreversible hydrogen bonding in the course of water movements within the pore system of the cell walls.

Little study has been done on the effects of heat-treatment on gas permeability of solid woods. The present study is, therefore, aimed at finding the effects of heat-treatment on gas permeability of several hardwoods. Also, to find the effects of heat-transfer properties of silver nanoparticles, a separate set of specimens were also prepared that were first impregnated with nanosilver suspension before heat treatment was applied to them and untreated specimens.

\section{Specimen Procurement}

Three hardwoods were chosen based on their importance in various industrial applications in Iran comprised of beech (Fagus orientalis), poplar (Populus nigra), and hornbeam (Carpinus betulus). Specimens of each species were divided into two main groups of heat-treated specimens (HT), and nano-silver-impregnated heat-treated specimens (NSI-HT). To minimize variation between HT and NSI-HT specimens, dowel-shape cylinders of $12 \mathrm{~cm}$ in length and $18 \mathrm{~mm}$ in diameter were procured in longitudinal direction of trees; two $5 \mathrm{~cm}$ long specimens were cut from each $12 \mathrm{~cm}$ long specimens; the upper specimens were kept as HT specimens, and the lower specimens were impregnated with nano-silver suspension once their specific gas permeability were measured. For every species, 20 pairs of specimens free from any knots, fissures, and checks were prepared. Furthermore, silicon adhesive was spread all around each specimen to prevent air flow through 
radial and tangential directions. In the meantime, to measure mass loss, some HT and NSI-HT specimens were randomly chosen to be put in oven along with gas permeability specimens. A separate set of specimens with the same size and specifications were procured for mass-loss measurement; only these specimens were not glued with silicon adhesive.

\section{Nano-silver Impregnation Process}

A 200 ppm aqueous dispersion of silver nanoparticles was produced and applied to the specimens using electrochemical technique in collaboration with Jafr Sorkhe Fajr Company. The size range of silver nanoparticles was 20-80 nm. The pH of the suspension was 6-7; two kinds of surfactants (anionic and cationic) were used in the suspension as stabilizer; the concentration of the surfactants was three times the nano-silver particles. Empty-cell impregnation process (Rueping method) was done in a 3 bar pressure vessel by Afshar Wood-Machinery Mfg. Co. (Ltd.). After impregnation, all HT and NSI-HT specimens were kept at room temperature for 4 months. Specific gas permeability values of NSI-HT specimens were again measured before heat-treatment process.

\section{Gas Permeability Measurement}

Longitudinal gas permeability measurement was carried out by an apparatus with milli-second precision designed and built by the author based on the microstructure porosity of wood (Taghiyari and Efhami 2011) (Fig. 1). Measurements were conducted using the falling water volume displacement method instructions (Siau 1971, Taghiyari et al. 2010, Dashti et al. 2012ab). All gas permeability specimens were cylindrical, $18 \mathrm{~mm}$ in diameter and $50 \mathrm{~mm}$ long to get the ultimate permeability values (Taghiyari and Sarvari 2010). 20 pairs of specimens were cut randomly at scattered locations from each disk. Connection between the specimen and holder was made fully air-tight. A pressure gauge with milli-bar precision was connected to the whole structure to monitor pressure gradient $(\Delta P)$ and vacuum pressure at any particular time as well as height of water column.

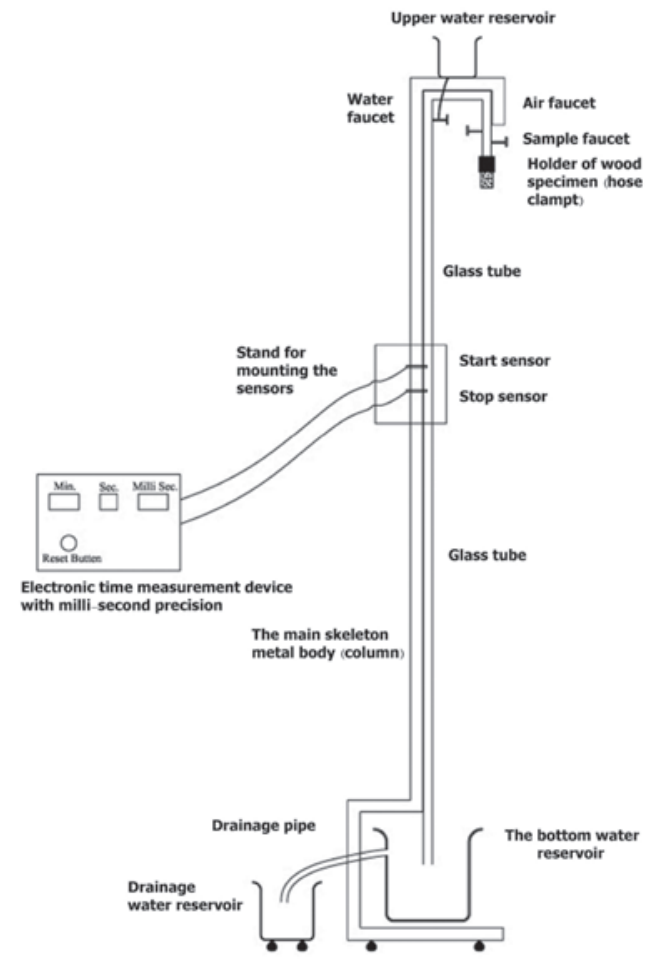

Figure 1. A schematic drawing of the gas permeability apparatus

(USPTO No. US 8,079,249, B2; Pub. No. 2010/0281951 A1) equipped with single-storey milli-second precision electronic time measurement device (Approved by The Iranian Research Organization for

Scientific and Technology under certificate No. 47022) 
Three measurements were taken for each specimen. Superficial permeability coefficient was then calculated using Siau's equations (Siau 1995) (Equations 1 and 2). The superficial permeability coefficients were then multiplied by the viscosity of air $\left(\mu=1.81 \times 10-5 \mathrm{~Pa}\right.$ s) for the calculation of the specific permeability $\left(K=k_{g} \mu\right)$.

$$
\begin{array}{r}
k_{g}=\frac{V_{d} C L\left(P_{a t m}-0.074 \bar{z}\right)}{t A(0.074 \bar{z})\left(P_{a t m}-0.037 \bar{z}\right)} \times \frac{0.760 \mathrm{mHg}}{1.013 \times 10^{6} \mathrm{~Pa}} \\
C=1+\frac{V_{r}(0.074 \Delta z)}{V_{d}\left(P_{a t m}-0.074 \bar{z}\right)}
\end{array}
$$

\section{Where:}

$k_{g} \quad=$ longitudinal specific permeability $\left(\mathrm{m}^{3} \mathrm{~m}^{-1}\right)$

$V_{d}=\pi r^{2} \Delta z[\mathrm{r}=$ radius of measuring tube $(\mathrm{m})]\left(\mathrm{m}^{3}\right)$

$C=$ correction factor for gas expansion as a result of change in static head and

$C=$ viscosity of water.

$\boldsymbol{L} \quad=$ length of wood specimen (m)

$P_{\text {atm }}=$ atmospheric pressure $(\mathrm{m} \mathrm{Hg})$

$\bar{z}=$ average height of water over surface of reservoir during period of

measurement $(\mathrm{m})$

$t=$ time (s)

$A=$ cross-sectional area of wood specimen $\left(\mathrm{m}^{2}\right)$

$\Delta z=$ change in height of water during time $\mathrm{t}(\mathrm{m})$

$V_{r} \quad=$ total volume of apparatus

$V_{r}=$ above point 1 (including volume of hoses) $\left(\mathrm{m}^{3}\right)$ 


\section{Liquid Permeability Measurement}

Liquid permeability was measured using RILEM test tube (Fig. 2). Two times were measured: 1- The time the first drop of water falls off the bottom surface of the $5 \mathrm{~cm}$ long specimen; 2- The time the level of water in RILEM tube lowers by $5 \mathrm{~cm}$ in the tube (that is, $6.6 \mathrm{CC}$ of water). The test for each specimen was considered done when the liquid level was lowered by 5-cm in the RILEM tube; that is, if the 1st-drop took more that 5-cm lowering time, no 1st-drop time was registered for that individual specimen.

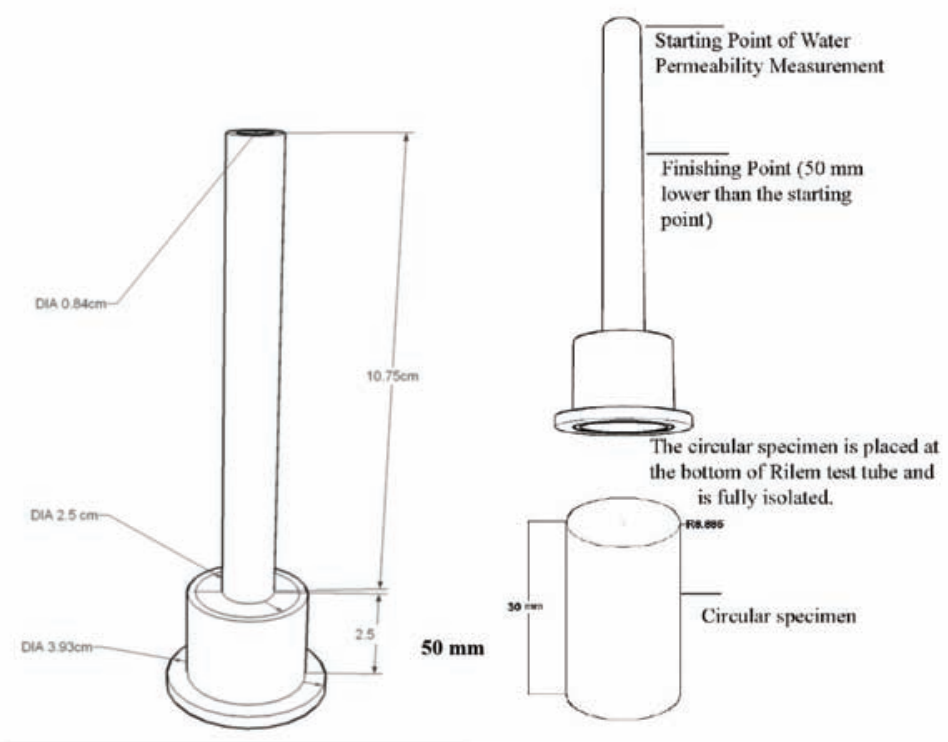

Figure 2. Liquid permeability measurement apparatus (RILEM test tube)

\section{Heat-Treatment Process}

All specimens (HT, NSI-HT, and mass-loss) were randomly arranged in an oven to be heated for 24 hours. Heat-treatment was done at consecutive steps of $50,75,100,125$, and $150^{\circ} \mathrm{C}$. At the final step, specimens were heated for 4 hours at $185^{\circ} \mathrm{C}$. After each step, gas permeability of each specimen was measured once the specimens were cooled off. Also, adhesive glue was checked, and if necessary replaced after each step to make sure no air flow through lateral directions.

\section{Mass-Loss Measurement}

Separate specimens with the same size and specifications were prepared from all three species for weight measurement after each heat-treatment steps. Mass-loss specimens of both HT and NSI-HT groups were randomly arranged in the oven along with gas permeability specimens. They were weighed with $0.0001 \mathrm{~g}$ digital scale after each heat-treatment step. Mass-loss specimens were free from adhesive glue.

\section{Statistical Analysis}

Statistical analysis was conducted with SAS software program, version 9.1 at $99 \%$ level of confidence. Regression analysis and hierarchical cluster, including dendrogram and using Ward methods with squared Euclidean distance intervals, was carried out by SPSS/16. 


\section{RESULTS AND DISCUSSION}

Results showed that specific gas permeability in longitudinal direction of all specimens had a sharp increase at two stages: first when NSI-HT specimens were impregnated by the nano-silver suspension, and second, when specimens were first heated at $50^{\circ} \mathrm{C}$ (Figures 3, 4, and 5). The sharp increase after nano-silver-impregnation process was because some of the extractives were washed out of wood specimens by the empty-cell process. Greatest increase was found in poplar specimens (136\%). In beech specimens, however, 4.2\% decrease was observed which was due to the settlement of silver nanoparticles within pits and scalariform perforation plates (Fig. 6) (Taghiyari 2012b).

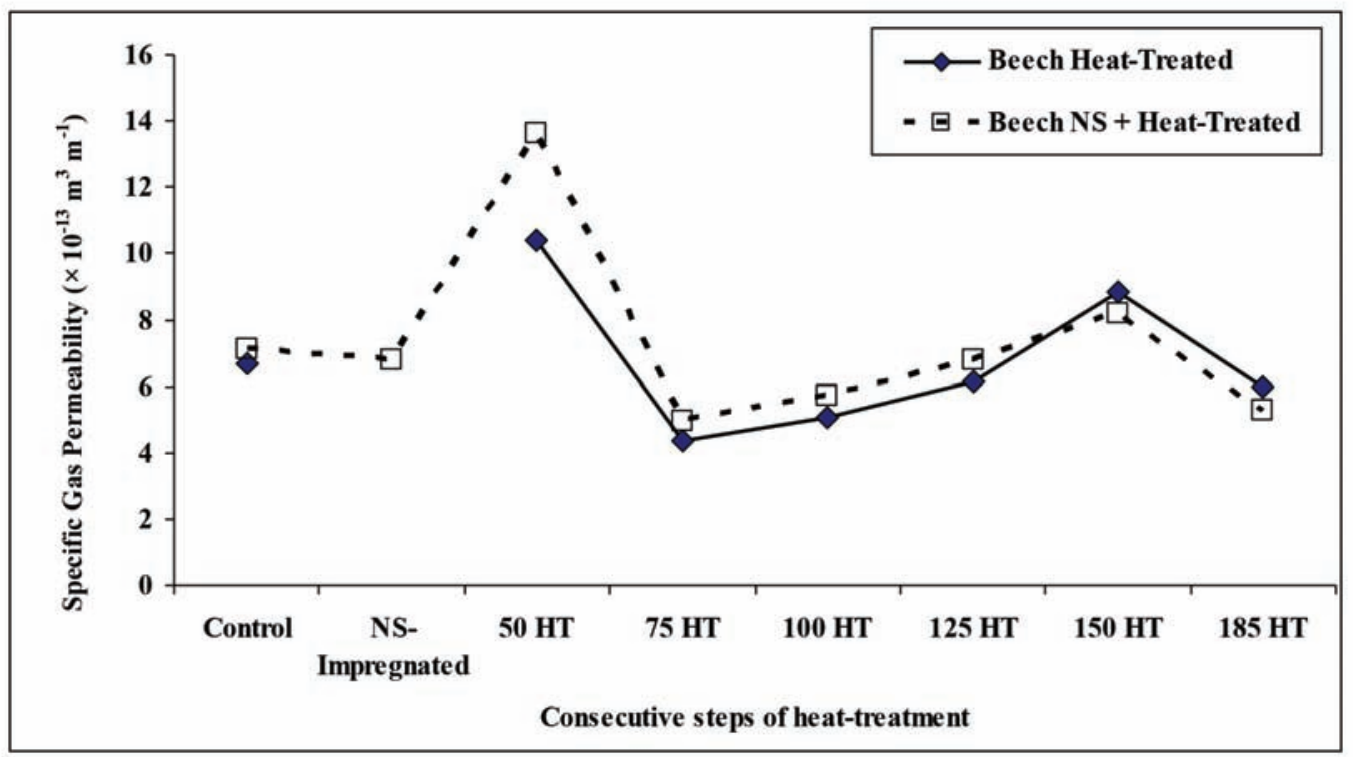

Figure 3. Specific gas permeability values for HT and NSI-HT beech specimen-pairs.

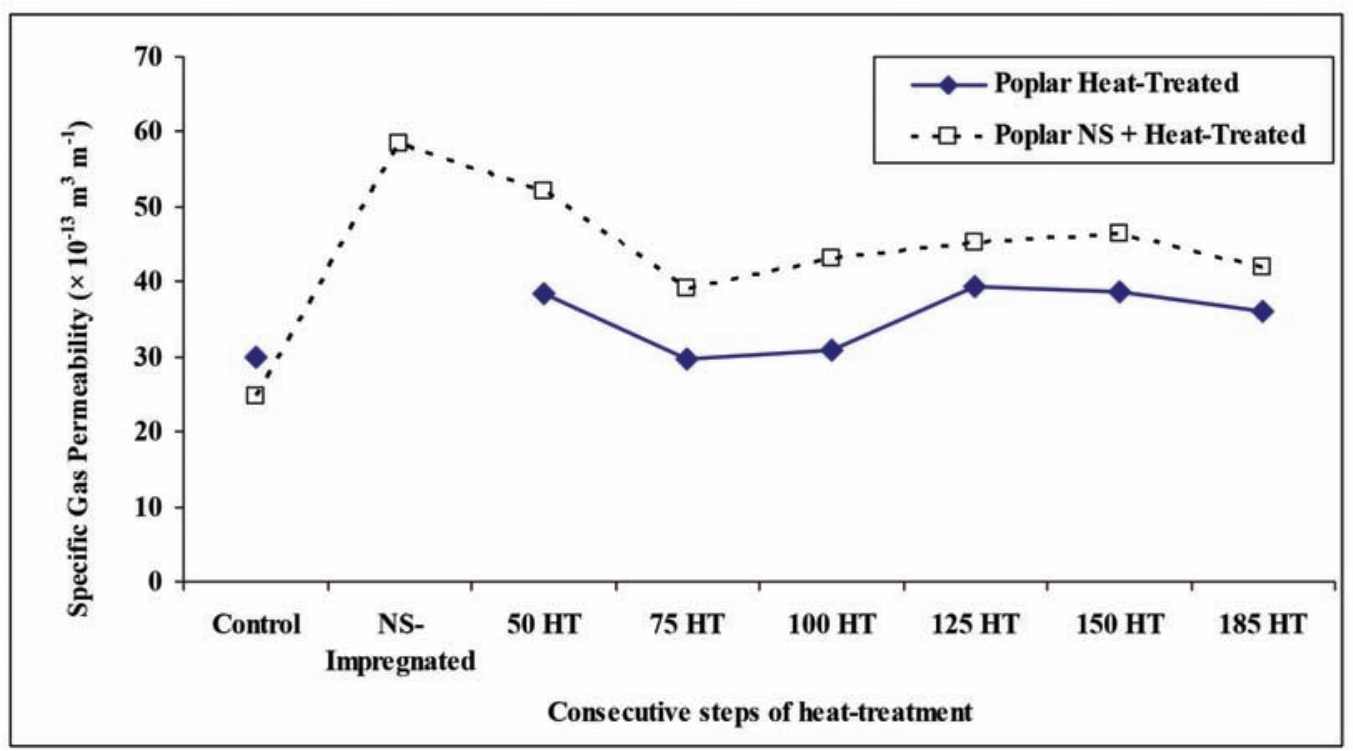

Figure 4. Specific gas permeability values for HT and NSI-HT poplar specimen-pairs. 


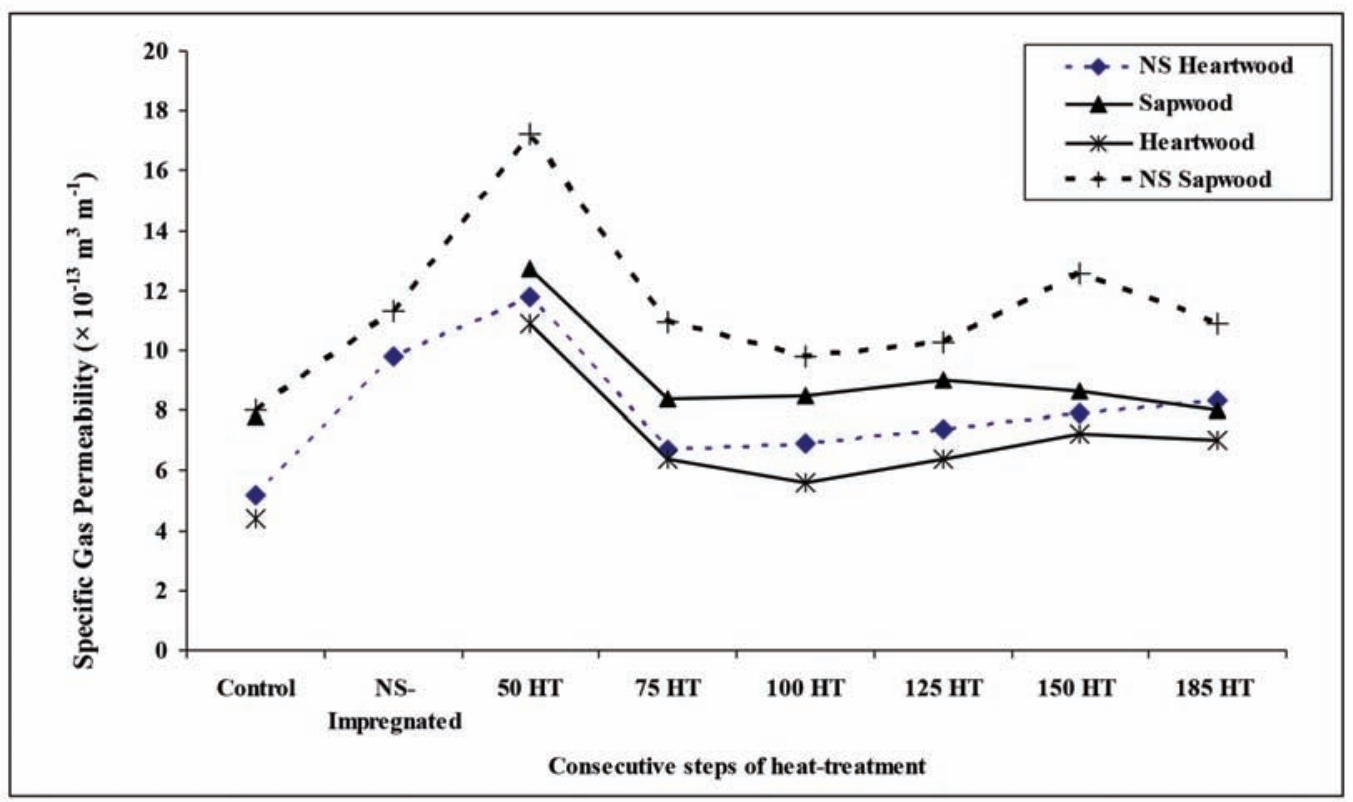

Figure 5. Specific gas permeability values for HT and NSI-HT hornbeam sapwood and heartwood specimen-pairs.
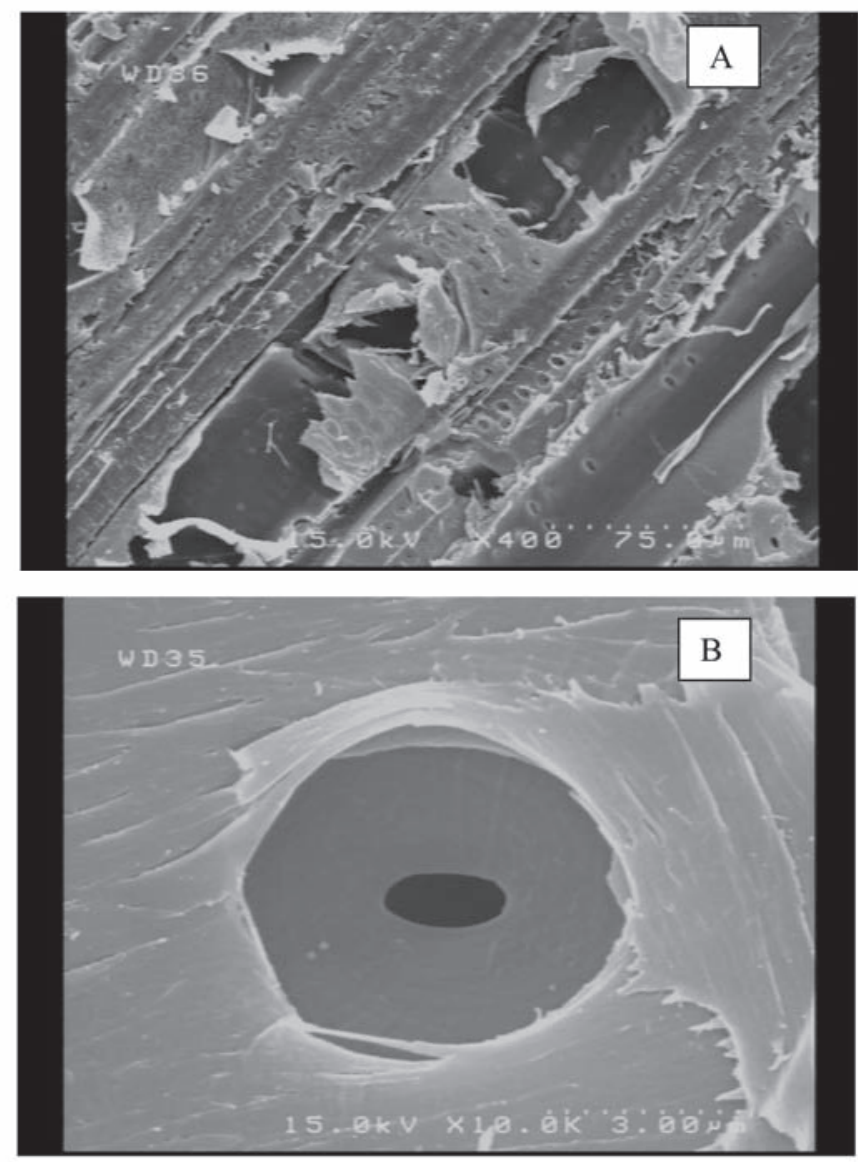

Figure 6. SEM micrographs of beech showing perforation plates in vessels (A), and a pit in the cell wall (B) 
All nano-silver-impregnated treatments showed an increase in gas permeability when heated at $50^{\circ} \mathrm{C}$, but poplar NSI-HT specimens showed a 10.9\% decrease (Fig. 4). The sharp increase at this step could have been due to loss of bound water causing vessel perforations and pits to become wide open by great shrinkage. There was however a sharp decrease in permeability at $75^{\circ} \mathrm{C}$ in all specimens. Structural modifications and chemical changes of lignin may have played an important role (Repellin and Guyonnet 2005). Furthermore, the irreversible hydrogen bonding in the course of water movements within the pore system also may have affected the fluid transfer process (Borrega and Karenhampi 2010). These processes may have occurred at lower temperatures in poplar, with the lowest density in the present study, causing the above mentioned slight decrease at $50^{\circ} \mathrm{C}$. Permeability values were then steadily increased in the further heat-treatment steps after $75^{\circ} \mathrm{C}$, and up-to $150^{\circ} \mathrm{C}$. In these steps, higher temperatures increase high internal stresses that are released as cracks (Oltean et al. 2007). These cracks facilitated fluid transfer process through the porous material causing the gradual increase in permeability.

Heat-treatment at the final step of $185^{\circ} \mathrm{C}$ made permeability values in nearly all species decrease (Fig. 5). Heat-conductivity of nano-silver particles made these processes intensified. Figures 7 and 8 show that heat-treated sapwood specimens has a great mass loss when they were heated at 150 and $185^{\circ} \mathrm{C}$. Similarly, a decreasing trend in gas permeability value may be observed in figure 5 . This may clearly imply that every mass loss should not necessarily end up in increase in permeability.

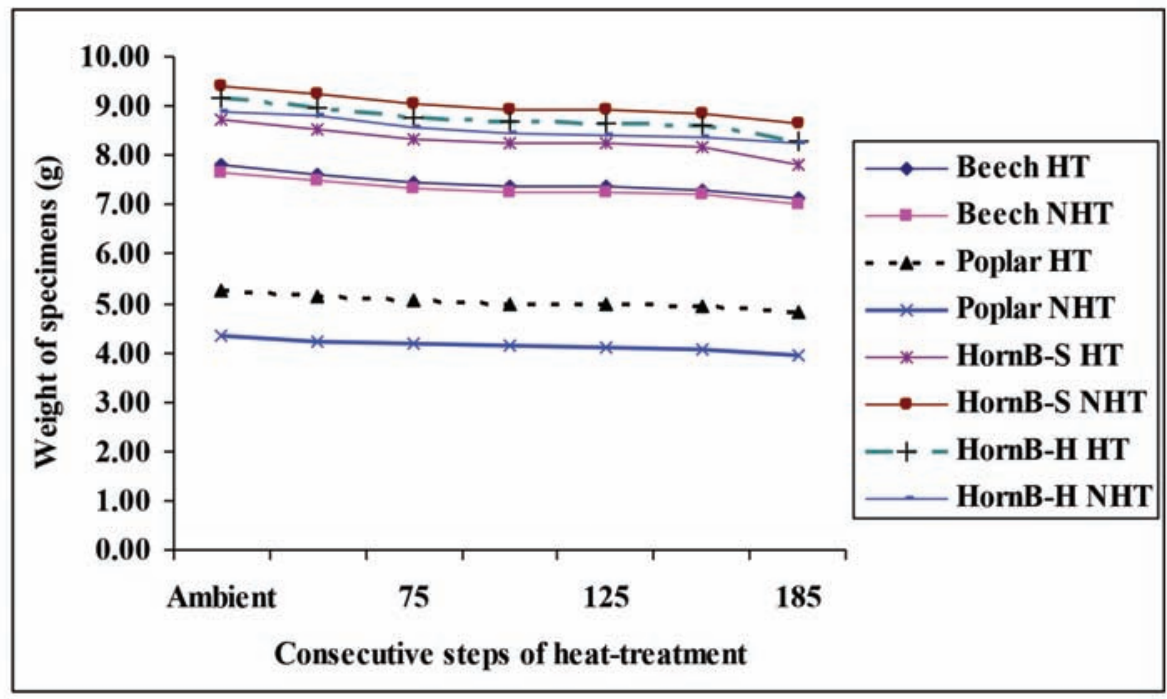

Figure 7. Weights of specimens at different steps of heat treatment (g) 


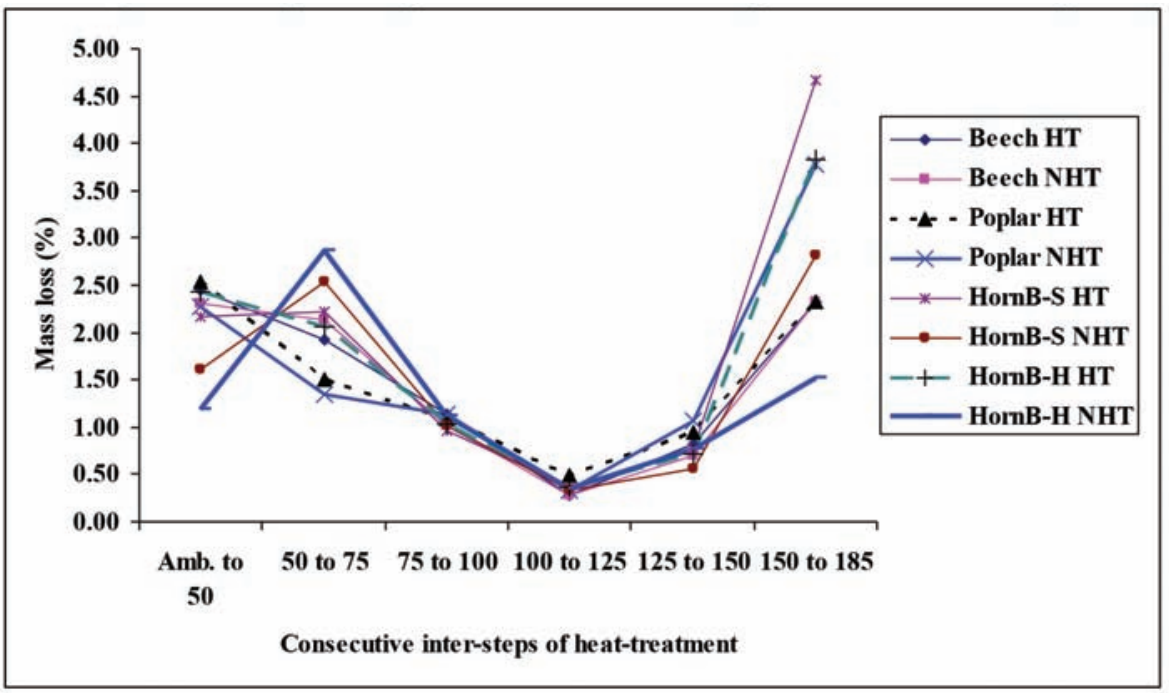

Figure 8. Percent of mass loss between different steps of heat treatment

Liquid permeability times (s) were measured once the specimens were heat-treated and finished with gas permeability measurement. Maximum liquid (water) permeability times were found in NSI-HT poplar specimens. Regression analysis between specific gas permeability time with the two liquid permeability times, after the heat-treatment, showed high relationship between gas permeability and 5-cm lowering times (Table 1). Cluster analysis of all the treatments based on gas and liquid permeability time values showed great similarity between HT and NSHT beech and poplar specimens, as well as HT and NSHT poplar specimens.

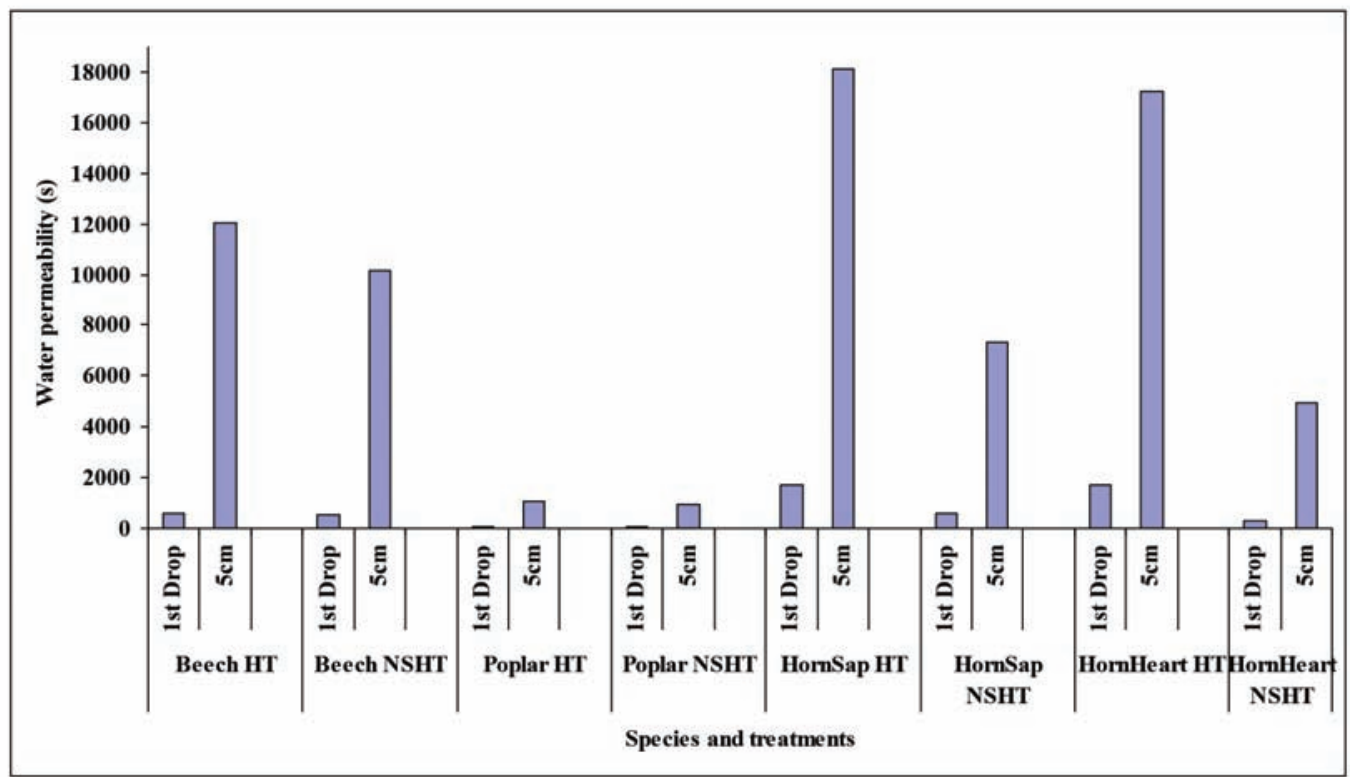

Figure 9. Liquid permeability times (s) of the different treatments of the present study (HT=HeatTreated; NSI-HT=Nano-Silver-Impregnated Heat-Treated) after $185^{\circ} \mathrm{C}$ heat treatment 
Table 1. Regressions analysis results for correlations between gas with liquid permeability (1st drop as well as 5 -cm lowering) times after heat-treatment at $185^{\circ} \mathrm{C}$.

\begin{tabular}{|c|c|c|c|c|c|c|c|c|}
\hline $\begin{array}{c}\text { Species } \\
\text { and } \\
\text { Treatments }\end{array}$ & $\begin{array}{c}\text { Poplar } \\
\text { (HT) }\end{array}$ & $\begin{array}{c}\text { Poplar } \\
\text { (NSI- } \\
\text { HT) }\end{array}$ & $\begin{array}{c}\text { Beech } \\
\text { (HT) }\end{array}$ & $\begin{array}{c}\text { Beech } \\
\text { (NSI- } \\
\text { HT) }\end{array}$ & $\begin{array}{c}\text { Hornbeam } \\
\text { Sapwood } \\
\text { (HT) }\end{array}$ & $\begin{array}{c}\text { Hornbeam } \\
\text { Sapwood } \\
\text { (NSI-HT) }\end{array}$ & $\begin{array}{c}\text { Hornbeam } \\
\text { Heartwood } \\
(\mathrm{HT})\end{array}$ & $\begin{array}{c}\text { Hornbeam } \\
\text { Heartwood } \\
\text { (NSI-HT) }\end{array}$ \\
\hline $\begin{array}{c}\text { R square } \\
\left(\mathrm{Gas}-1^{\text {st }} \text { drop) }\right.\end{array}$ & $\begin{array}{c}.960 \\
* *(+) \\
\end{array}$ & $\begin{array}{c}.998 \\
* *(+) \\
\end{array}$ & -..-- & $\begin{array}{l}1.000 \\
* *(+) \\
\end{array}$ & $\begin{array}{c}.281 \\
\text { NS (-) } \\
\end{array}$ & $\begin{array}{c}.240 \\
\text { NS (-) }\end{array}$ & -........ & $\begin{array}{c}396 \\
\mathrm{NS}(+) \\
\end{array}$ \\
\hline $\begin{array}{c}\text { R square } \\
(\mathrm{Gas}-5 \mathrm{~cm})\end{array}$ & $\begin{array}{c}.960 \\
* *(+) \\
\end{array}$ & $\begin{array}{c}.998 \\
* *(+) \\
\end{array}$ & $\begin{array}{c}.963 \\
* *(+) \\
\end{array}$ & $\begin{array}{c}.970 \\
* *(+) \\
\end{array}$ & $\begin{array}{c}.608 \\
* *(+) \\
\end{array}$ & $\begin{array}{c}.124 \\
\text { NS (+) }\end{array}$ & $\begin{array}{c}.858 \\
\text { NS }(+)\end{array}$ & $\begin{array}{c}.946 \\
* *(+)\end{array}$ \\
\hline
\end{tabular}

** Statistically significant at $1 \%$ confidence level.

* Statistically significant at $5 \%$ confidence level.

HT Heat-Treated.

NSI-HT Nano-Silver-Impregnated Heat-Treated.

NS Not Significant.

() positive $(+)$ or negative ( - ) correlation

Mass loss of all species and treatments in the present study showed constant decrease from ambient temperature up-to $185^{\circ} \mathrm{C}$ (Fig. 7). Calculation of the percent of mass loss though showed that the maximum mass loss took place at 3 steps: 1 - when specimens were first heated at $50^{\circ} \mathrm{C}, 2$ - when they were heated at $75^{\circ} \mathrm{C}$, and 3- when they were heated at $185^{\circ} \mathrm{C}$ (Fig. 8). Apart from the first step when the specimens were heated from ambient temperature to $50^{\circ} \mathrm{C}$ causing a sharp increase in permeability, the other two peaks of mass loss shown in figure 8 (when heated at $75^{\circ} \mathrm{C}$ and $185^{\circ} \mathrm{C}$ ) resulted in considerable decrease in gas permeability (Figures 3, 4, and 5).

SEM micrographs showed spread of nano-silver particles over the surface area of specimens. The effects of nano-silver particles were quite different at lower temperatures in comparison with higher temperatures. At lower temperatures of less that $125^{\circ} \mathrm{C}$, NS particles accelerate the process of heat-transfer to the inner parts of specimens and therefore evaporation of volatiles was more easily done also in the core of specimens. At temperatures more that $125^{\circ} \mathrm{C}$, on the other hand, heat-conductivity property of NS-particles made concentration of heat to less degrees on the surface layer of specimens and therefore lower mass-loss could be expected in the specimens (Fig. 8).

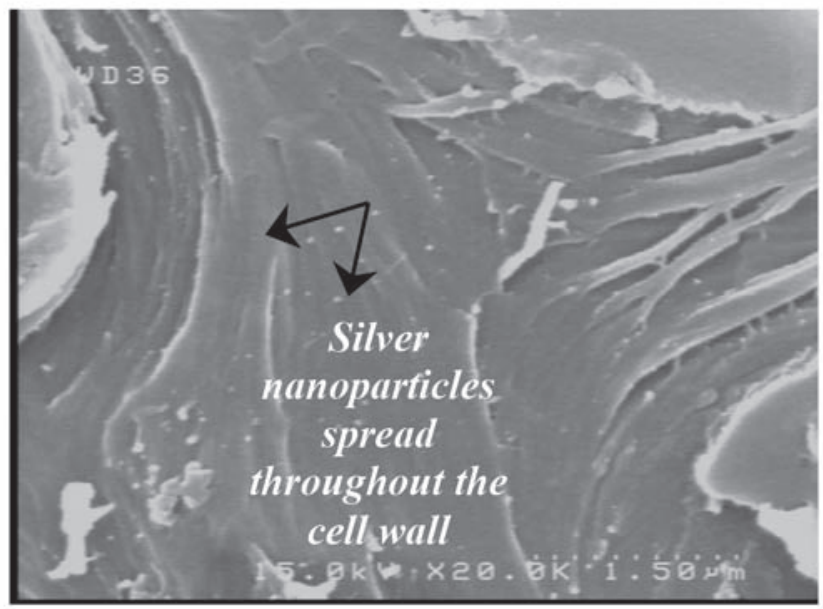

Figure 10. SEM micrograph of nano-silver-impregnated beech showing silver nanoparticless all over the cell wall 
Oltean et al. (2007) indicated that only a few papers dealt with the influence of temperature during drying on both the mechanical properties of wood and on the occurrence of cracks. Gas permeability may be considered a suitable means to estimate the extent of degradation of wood components and cracking. At lower temperatures, when gas permeability increased, possibly significant degradation of wood components occurred. At higher temperatures when permeability showed a gradual increase, the internal stresses might have resulted in (micro-) cracks within cell walls.

Based on the above mentioned findings on the effects of heat-treatment on permeability, when wood specimens are to be dried for industrial or scientific purposes for further processes, it would be more logical to heat them at temperatures less than $60^{\circ} \mathrm{C}$ even if that means longer times of keeping the samples in oven or kiln because this would keep specimens on the safe edge of not being irreversibly changed in their structure and chemical components, as well as permeability and impregnability properties.

\section{CONCLUSIONS}

Heat-treatment affects permeability significantly due to loss of bound water and irreversible hydrogen bonding in the course of water movements within the vessel perforations and pore system of cell walls.

Heat-conductivity of nano-silver particles intensifies the effects of heat-treatment.

For heat-treated specimens, liquid permeability of $5-\mathrm{cm}$ lowering time gives a better estimate of specific gas permeability value.

In processes where the permeability of solid woods are important, the wood should not be heated at temperatures higher than $60^{\circ} \mathrm{C}$ to prevent irreversible structural or chemical changes in the cell wall components.

\section{ACKNOWLEDGMENTS}

Technical help of Engines. Ali Azimbagi-Rad in the design and production of the gas permeability apparatus is highly appreciated. Author is grateful to Mr. Meghdad Esmaiilzadeh Bozabadi and Mr. Farhad Aminzadeh Liyafooii (active members of Wood Sic. \& Tech. Scientific Association of SRTTU) for their great help in gas permeability specimen preparation, measurement, and heat-treatment.

\section{REFERENCES}

Awoyemi, L.; Westermark, U. 2005. Effects of Borate Impregnation on the Response of Wood Strength to Heat Treatment. Wood Sci Technol 39: 484-491.

Awoyemi, L. 2007. Determination of Optimum Borate Concentration for Alleviating Strength Loss During Heat Treatment of Wood. Wood Sci Technol 42: 39- 45.

Borrega, M.; Karenlampi, P.P. 2010. Hygroscopicity of Heat-Treated Norway Spruce (Picea abies) wood. Eur J Wood Prod 68(2): 233-235. DOI 10.1007/s00107-0090371-8.

Chen, P.Y.S.; Zhang, G.; Van Sambeek, J.W. 1998. Relationships among growth rate, vessel lumen area, and wood permeability for three central hardwood species. Forest Prod J 48(3): 87-90.

Dashti, H.; Shahverdi, M.; Taghiyari, H.R.; Salehpur, Sh.; Heshmati, S. 2012a. Effects of steaming and microwave pretreatments on mass transfer characteristics of Aleppe oak (Quercus infectoria). Bioresources 7(3): 3262- 3273.

Dashti, H.; Salehpur, Sh.; Taghiyari, H.R.; Akbarifar, F.; Heshmati, S. 2012b. The effect of nanoclay on the mass transfer properties of plywood. Digest Journal of Nanomaterials and Biostructures 7(3): 853-860.

Dermoe, D.; Zillig, W.; Carmeliet, J. 2012. Variation of measured cross-sectional cell dimensions and calculated water vapor permeability across a single growth ring of spruce wood. Wood Science and Technology 46: 827-840.

Elder, T. 1991. The Pyrolysis of Wood; In: Wood and Cellulosic Chemistry, Hon, D.N.S. and Shiraishi, N. (Eds.). Marcel Dekker, New York, USA, pp. 665-699.

Garrote, G.; Dominguez, H.; Parajo, J.C. 1999. Hydrothermal Processing of Lignocellulosic Materials. Holz als Roh-und Werkstof 57(3): 191-202. 
Hill, C. 2006. Wood Modification Chemical, Thermal and Other Processes. John Wiley \& Sons, Ltd., ISBN: 0-470-02172-1; pp 239.

Oltean, L.; Teischinger, A.; Hansmann, C. 2007. Influence of Temperature on Cracking and Mechanical Properties of Wood During Wood Drying - A Review. BioResources 2(4): 789-811.

Repellin, V.; Guyonnet, R. 2005. Evaluation of Heat Treated Wood Swelling by Differential Scanning Calorimetry in Relation with Chemical Composition. Holzforschung 59(1): 28-34.

Rassam, Gh.; Ghofrani, M.; Taghiyari, H.R.; Jamnani, B. 2012. Mechanical performance and dimensional stability of nano-silver impregnated densified spruce wood. Eur J Wood Prod 70:595-600.

Siau, J.F. 1971. Flow in Wood. Syracuse University Press, Syracuse. USA. pp. 131.

Siau, J.F. 1995. Wood: Influence of Moisture on Physical Properties. Blacksburg, VA, Department of Wood Science and Forest Products Virginian Polytechnic Institute and State University, 1-63.

Stamm, A.J,; Burr, H.K.; Kline, A.A. 1946. Staybwood. Heat Stabilized Wood. Industrial and Engineering Chemistry 38 (6): 630 - 634 .

Taghiyari, H.R.; Karimi, A.N.; Parsapajouh, D.; Pourtahmasi, K. 2010. Study on the Longitudinal Gas Permeability of Juvenile Wood and Mature Wood. Special Topics \& Reviews in Porous Media 1(1): 31-38.

Taghiyari, H.R.; Sarvari S, Y. 2010. Ultimate Length for Reporting Gas Permeability of Carpinus betulus Wood. Special Topics \& Reviews in Porous Media 1(4): 345-351.

Taghiyari, H.R. 2011a. Effects of nano-silver on gas and liquid permeability of particleboard. Digest Journal of Nanomaterials and Bioresources 6(4): 1509-1517.

Taghiyari, H.R. 2011b. Study on the Effect of Nano-Silver Impregnation on Mechanical Properties of HeatTreated Populus nigra. Wood Sci Technol 45: 399- 404.

Taghiyari, H.R.; Efhami, D. 2011. Diameter increment response of Populus nigra var. betulifolia induced by alfalfa. Austrian Journal of Forest Science 128(2): 113-127.

Taghiyari, H.R.; Rangavar, H.; Farajpour Bibalan, O. 2011. Nano-Silver in Particleboard. BioResources 6(4): 4067-4075.

Taghiyari, H.R.; Rassam, Gh.; Lotfinejad Sani, Y.; Karimi, A. 2012a. Effects of nano-silver impregnation on some mechanical properties of ice-blasted specimens prepared from two native species. Journal of Tropical Forest Science 24(1): 83-88.

Taghiyari, H.R.; Layeghi, M.; Aminzadeh Liyafooee, F. 2012b. Effects of dry ice on gas permeability of nano-silver-impregnated Populus nigra and Fagus orientalis. IET Nanobiotechnology 6(2):40-44.

Taghiyari, H.R.; Gholamiyan, H.; Karimi, A. 2012c. Effects of Heat-Treatment on Screw and Nail Withdrawal Resistance of Nanosilver-Impregnated and Untreated Solid Woods. Current Nanoscience 8(4): 637-642.

Taghiyari, H.R.; Farajpour B, O. 2013. Effect of copper nanoparticles on permeability, physical, and mechanical properties of particleboard. Springer: Wood Sci Technol 71:69-77.

Taghiyari, H.R. 2012a. Fire-Retarding Properties of Nano-Silver in Solid Woods. Springer: Wood Sci. Technol 46: 939-952.

Taghiyari, H.R. 2012b. Correlation between Gas and Liquid Permeabilities in some Nano-Silver-Impregnated and Untreated Hardwoods. Journal of Tropical Forest Science 24(2): 249-255.

Tiemann, H.D. 1915. The Effect of Different Methods of Drying on the strength of Wood. Lumber World Review 28(7): 19-20. 